IIUM Journal of Educational Studies, 1:1 (2013) 55-97

Copyright (C) IIUM Press

\title{
THE EFFECT OF PARENTAL DIVORCE ON THE PSYCHOLOGICAL WELLBEING OF MUSLIM YOUTH: IMPLICATIONS FOR COUNSELING AND PSYCHOTHERAPY
}

\section{Daisy Jehaan Corpin Orcullo \& Nik Ahmad Hisham Ismail}

\begin{abstract}
This research deals with the experiences and perceptions of Muslim children and adolescents of divorced parents. The study, therefore, focuses on Muslim adolescents who went through the emotional trauma and impact of their parents' divorce but who have managed to let go of their negative reactions and to learn from the whole experience. Because the participants in this study are Muslims, another aspect that this research has looked into is the extent to which their faith, Islam, acted as a spiritual comfort.
\end{abstract}

\section{Introduction}

The rates of divorce are increasing in Muslim Countries. Islamic countries (i.e. Saudi Arabia and other Gulf states as well as the Middle East) allow divorce under the Shari'a or Islamic Law. In Southeast Asia, a good example is Malaysia. Dr. Mafauzy Mohamed, USM Health Director was quoted saying that the overall divorce rate among Malay Muslims was between $10 \%$ to 15\% (Bernama, Kuala Lumpur, 2005). He further said that the latest studies conducted by JAKIM (Malaysian Islamic Development Department) found out that 21\% of these cases was caused by irresponsibility of both spouses while $19.3 \%$ was because of incompatibility. The other causes were health risk, husband's having a second wife, and instability of marriage. Duffy (1991) explains that divorce only becomes legitimate if the laws (either Western or Islamic) sanction it. Thus, in countries where divorce is legal or accepted, couples have the choice to get divorced.

The family is the source of emotional support, comfort, warmth, protection, and security. However, there is always an opposite side of almost everything. Where there are 
families who enjoy the bliss, there are thousands of families who also suffer the pain and sadness of a broken family relationship. And one significant point is when mothers and fathers have decided to take the road of separation. This happens when mothers and fathers decide to either terminate the marriage or to separate. Consequently, the family loses its grip and the members suffer. As shown in qualitative and quantitative studies (Amato \& Keith, 1991; Cantin \& Boivin, 2004) parents' separation or divorce has tremendous effects on children.

To explore the perceptions and experiences of children on their parents' divorce is a challenging task because it affects the emotional and mental well-being of their children. Parents should be aware and cautious of their actions because they are the lifetime models of their own children. Some psychologists argue that divorce makes children vulnerable to depression and other psychological disorders. On the other hand, there are empirical studies that parental discord before and after a divorce influences children's adjustment more powerfully than does the actual divorce itself (Derdyn 1974).

Divorce as a solution to marital rifts is usually agreed upon by the persons involved. Studies show that even in Western societies where divorce is legal, going through custody of children and other requirements have long term effects on children (Laumann-Billings \& Emery, 2000; Chase-Lansdale, Cherlin \& Kierman, 1995). This means that the effects of divorce are unpredictable across race and culture and the extent of its psychological impact to children cannot be generalized. It is from this standpoint that I conceptualize my study on Muslim adolescents' experiences and perceptions on divorce.

\section{Focus of the Present Study}

The purpose of the present study was to explore the participant's experiences on parental divorce; understand the meanings of their experiences; identify the coping process from the Islamic perspective; and recommend a counseling program to assist children of divorced parents. In order to guide the thrust of the study, two important questions were addressed: What are the experiences of Muslim Children with parental divorce and what is the impact of 
IIUM Journal of Educational Studies, 1:1 (2013) 55-97

Copyright (C) IIUM Press

divorce to Muslim children? How do Islamic practices help them cope with the experience?

\section{Method}

This study employed the qualitative approach of phenomenological inquiry in gaining the participants' experiences of the issue at stake. Titchen (2000) explains that phenomenology is the study of lived human phenomena within the everyday social contexts in which the phenomena occur from the perspective of those who experience them.

The paradigm of phenomenology is designed to deeply analyze the personal life experience that is not easily measured through surveys or direct observation (Peterson, \& Jenni, 2003). Probing into the "unquantifiable" aspects of a phenomenon enables researchers to understand human experience and the ways in which humans interpret the meaningful strands of experiences (Peterson, 2003). Similarly, Merriam (2002) asserts that phenomenological research does not seek to arrive at verifiable claims about the nature of reality, nor does it describe reality objectively, but rather describes subjective human experience through an analysis that seeks to understand the essential structures of a given phenomenon as it appears in the conscious state.

\section{Sources of Information}

Phenomenological inquiry was done by individual in-depth interviewing, not only once but twice, from the month of September 2008 to January 2009.

To supplement the information, the researcher also conducted casual conversations with the mothers of the Filipino participants followed by inquiry on how it affects her children.

Each interview lasted for an hour and thirty minutes. All of the participants were students either in the collegiate or in the secondary level. Four of the participants were Malaysians, two were Filipinos, one was Maldivian. All of them were from Muslim families and they themselves professed that Islam is their religion. 
IIUM Journal of Educational Studies, 1:1 (2013) 55-97

Copyright (C) IIUM Press

Following the academic tradition, pseudonyms were used to refer to all participants of this study in order to protect their identity and privacy. Although one of the participants allowed the researcher to revealed her real identity, due to ethical considerations, and for the sake of other participants, her wish was not granted.

\section{Participants}

The procedure of purposive maximal variation sampling was applied in this study. Patton (1990) defined it as a strategy in which the researcher samples cases or individuals that differ on some characteristic or trait (i.e. different age groups). It intentionally selects individuals or sites in order to learn and understand the phenomenon. However, it established a standard means in choosing participants and sites that are "phenomenon rich". In this particular study, not only in the different age groups inwhich the seven (7) participants vary, but also in the number of years since the divorce took place and the specific age at which the participants experienced parental divorce.

On the number of participants, phenomenological research varies widely among studies (Polkinghorne, 1989, cited by Peterson, 2003). In this study, the researcher recruited seven (7) adolescents who willingly voluntered to discuss their experiences with parental divorce. Two of the participants were students at UCSU University Malaysia, three were students at the International Islamic University Malaysia IIUM, and another two were secondary school students in the Philippines.

Participants' ages ranged from 16-24 years old at the time of interview.

\section{Findings}

Because phenomenology is heavily anchored on peculiarities and social context, the participants' lived experiences are interpreted as themes that broadly delineate the effects of divorce. In this chapter, the experiences which encompass the psychological and emotional states that the Muslim adolescents had to confront with as helpless victims of parental divorce are reduced as phenomenological frames, namely internalizing effect, externalizing effects, and mediating effects. As the exploration and understanding of each frame go deeper and 
IIUM Journal of Educational Studies, 1:1 (2013) 55-97

Copyright (C) IIUM Press

become more personal, various concepts emerge. Apparently, by associating phenomenological frames as themes and concepts as sub-themes, the phenomenon of parental divorce is also addressed in its social context.

Towards this end, the interpretation centers on three phenomenological frames. Based on the participants' accounts, the first frame on internalizing effects employs the direct approach of lived experiences, which are further categorized into inciting negative reactions and continuing impact of divorce. The second frame on externalizing effects uses the indirect approach that results in providing risks and eliciting some positive effects. The last frame on mediating effects combines the direct and indirect approaches and discusses coping and healing strategies and perceptions on family and marriage. The chapter ends with a synthesis of the analysis.

\section{Internalizing Effects of Parental Divorce}

Listening to the participants' accounts of parental divorce unravels the past with fragmented experiences of dissociation from parent-child relationships. The unfolding of meanings and categorizing them into emotional and behavioral manifestations demonstrate the severity of parental divorce in the lives of the seven participants. Specifically, the data was transcribed, categorized, and synthesized into phenomenological frames. Accounts of the participants' experiences on parental divorce happened from three (3) to seven (7) years back. Their recollection of what transpired before, during, and after parental divorce was relatively controlled, with no apparent harsh, forceful or robust physical reactions because the experiences were either rationalized or sustained in a considerable period of time.

Hypothetically, if they were left silent of the whole experience, they would likely ignore their feelings or allow themselves be swallowed by constant questioning "why the divorce happened" with no evident answers but to blame their parents. Nevertheless, despite moderation of emotional tone, some participants expressed some subtle outward reactions during the interview. Since the participants were composed of different nationalities and languages, the accounts were presented in two ways: first, for Fatimah and Hadiyah, the 
Visayan account was given first, then an English translation; second, for Ahmad, Hashim, Aminah, Nasheeda, and Karima, their accounts were all in English.

\section{Inciting Negative Reactions}

Parental divorce affects a child's emotional development and proves detrimental to the self. Children reared in a "normal" environment with two individuals as parents are generally perceived to exhibit well-adjusted behaviour. On the other hand, children whose formative years experience a break from the expected norm (i.e. due to separation or divorce) suffer emotional stress. Thus, the developmental stage is crucial because it determines what the child is doing, thinking, and feeling at the time of the divorce. At the same time, when children realize that the persons they are attached with are no longer around for various reasons, the immediate reaction is the loss of affection and love. They tend to form negative notions towards their parents who are the primary sources of affection, protection, and care. To discuss how attachment and adjustment manifest in the lives of the Muslim adolescents, their accounts are explored and understood with the phenomenological frame of internal effects of their parent's divorce.

\section{Initial Reactions: Hurt, Disappointment, Frustration, and Confusion}

Among the seven participants, only three were children when their parents divorced: Aminah and Hadiyah were seven years old while Fatimah was eight years old. The remaining four were already in their teens: Karima and Hashim were 14 years old while Nasheeda and Ahmad were 16 years old. Although all of them used common words to express their sentiments on their parents' divorce, the intensity varied as each tried to recall the circumstances of the divorce. In this sub-section, the participants were clustered based on the perceived cause/s of their parent's divorce. Feelings are profoundly shaped by context, and parental divorce involves parents as well as children. In other words, the participants' initial reactions were triggered by two interrelated phenomena: separation and divorce. Three of the participants' accounts were interpreted as Parent-Child Separation. The first details the lived experiences of the sisters Fatimah and Hadiyah, focusing on their father's overseas 
employment. The second case expounds the story of Aminah whose mother left her and an older sister to work in the United States.

Father Separation. Fatimah is the eldest child among six children of two girls and four boys. Next to her is Hadiyah, another participant in the study. Their father Jalil used to work as purchaser in a madrasah (Islamic school) for years from which he earned a sufficient income. However, looking forward to his children's education, that job could no longer address the increasing needs of the family. Consequently, he decided to enrol in an IT short course after which he went to Saudi Arabia in 1999 for a clerical post when Fatimah was eight years while Hadiyah was seven year old. Determined to work for his family's welfare, Jalil endured the job for one year. He claimed that his supervisor was condescending to him and other migrant workers. His employer, however, allowed him to take a leave of absence to visit his family in the Philippines in 2000. After enjoying his paid leave for two months, he went back to Saudi and resumed his clerical job in the same company. But things turned sour between him and his supervisor, so he resigned. Instead of going back to his wife and children in the Philippines, however, he took the risk of going to Canada upon the invitation of another Muslim convert he met online.

The fleeting romance with Zainab, a Filipino-Canadian widow enabled him to secure a visa and find temporary work in Canada. He continued sending money to his family in the Philippines. After awhile he appealed to his wife, Sarah to divorce him in paper only, which Sarah rejected. According to her, "I am a Muslim and I know deep in my heart that there is no such thing as divorce for convenience". Eventally, however, in 2001, Sarah filed for a divorce, sent him the papers, and became a single mother. Through the years, Sarah and her children have been on their own, and although they receive regularly their monthly stipend, things have never been the same. When Jalil paid them a visit in 2008, he wanted to reconcile with Sarah, insisting that their marriage was still binding because as far as he is concerned, the paper she sent to Canada only facilitated his legal marriage to Zainab and did not nullify his rights as Sarah's husband. Sarah on the other hand stood firm with her decision. 
Asked about how she felt about the divorce, Fatimah answered in a low tone, head down. She expressed her hurts, sadness, and disappointments about her parents' separation as follows:

Kato jud hinuon nga mga panahon, nahiubos jud ko ni Tatay. Wala nako ma "expect" nga mahitabo to kay niadto ra man to sya sa Saudi, aron manarbaho, pero ambot mangasawa man diay sya ug lain, dayun e "divorce" pa jud daw si Nanay, sakit kaau para nako. Maau man unta among pagpamuyo, malipayon mi bisan naa problema sa "financial", pero kung ang iyang pagpanarbaho sa abroad mag divorce lang sila ni Nanay maau pa wala nalang sya molakaw. Diba "frustrating" kaau?

[At that time, I was really hurt. I did not expect that it would happen (referring to her father's decision to divorce her mother). I thought he went to Saudi to work. It never entered my mind that he would find another woman and that he would divorce mom. It was very painful. We were a happy family even if sometimes, we had financial problems. If his going overseas is the cause of the divorce, it would have been best for us if he didn't take the job. It's very frustrating, isn't it?]

It is obvious from Fatimah's recollection that she was deeply hurt. She was close to tears because for her, the circumstances that led to her parents' divorce were vague. Going through the transcript, there are three possible reasons: first, she understood why her father had to leave them; second, she was disappointed because her father had another woman; third, she was frustrated when her father decided to divorce her mother. These reasons are not typical of an eight-year old, but any child who was raised in a "happy family" would certainly value family over comfort. Fatimah invited the researcher into her emotional state by saying, "It's frustrating, isn't it?" because in retrospection, she wished that her father did not go overseas. Her conflicting emotions revealed that she would rather choose an intact family despite the meager income of her father rather than a broken family. Although the issue of separation was aggravated by a third party, it was Hadiyah who suggested a more lucid backdrop of their father's decision to leave the family for good.

Throughout the interview session, the sisters Fatimah and Hadiyah were together. As the interview progressed, their accounts overlapped but in the end, I was able to draw a line between Hadiyah's initial reactions from Fatimah's. Both of them experienced the separation, but Hadiyah, who is a year younger that Fatimah, viewed and perceived the divorce quite 
differently. Hadiyah's account emphasized that she was very close to her father. When she recalled the separation which resulted in divorce, she had this to say:

Nasuko jud ko Tatay. Naglagot ko kay nganu man bulagan niya si Nanay...ug mangasawa pa jud ug lain nga babaye... Unsa man diay nang babaye datu? Dayun, layo na ra ba sya amo...dayun ingon ani iyang himuon. Naglisud na gani, mangasawa na hinuon... Oo, gamay pa man ko ato, pero nakasabut nako kay cge man ug hilak si Nanay unya iya man mi giingnan nga magbulag lage kuno sila. "Close" baya ko kang Tatay pero naglagot nako niya atong panahona.

[I was very angry at my dad. My anger was a mixture of frustration and hurt. Why did he have to divorce my mum... and take another wife? Was that woman rich? He was away from us... and suddenly, he left us for another woman. We were in difficult times but for him, he wanted to have another wife... I was young at that time, but I felt that there was something wrong because mum always cried. Later, mum informed us that she would divorce dad. I was close to my dad but his decision hurt me so much.]

Although Hadiyah tried to remain calm, her account was full of pauses and she talked slowly. Her words were harsh towards her father who might have been lured by a rich woman. Hadiyah's anger was real because she did not only lose a father. Above all, she lost a best friend. Being devoted to her dad, she felt cheated and unwanted. Seeing her mother cry intensified the indignation she felt for him because apart from his absence, there was another woman. While the separation was temporary (i.e. the father left for economic reason), she had accepted it. What she found very painful was her attachment to her father and his act of betrayal towards her mother.

Hadiyah's emotional disclosure was shown in her blushed face, restless hands and sighs. Gathering her thoughts while recalling her feelings, she leaned towards me for comfort.

Later, in a sober mood, her voice dropping octave lower, she explained:

"Close” man jud mi ni Tatay...ug katong sa iyang paglakaw aron manarbaho abroad, kami tanan naguol kay malayo na sya sa amo, labi na ako. Ni "embrace" lang ko niya pero nitago dayun ko kay perti man nako'g hilak sa kuarto aron dili ko nila makita gi-sirad-an nako ang among kuarto... Mingawon man jud ko niya.

[I was very attached to my dad... the day he left to work overseas, everyone was unhappy because he would be away from us. I was affected more than my other siblings. After I embraced him, I immediately ran away and locked myself in the room to cry. I didn't want them to see me crying... I did it because I would be missing him.] 
Recalling those moments of intense pain she gave way to tears. Unlike Fatimah, Hadiyah poured her heart out because the separation made her remember the pain of seeing her father go. Although the embrace was brief and tender, it was a lasting reminder of their closeness. Her tears were real and all she could do was treasure the happy memories with him. Hadiyah was heartbroken by the separation because all her life, she had felt that her father loved all of them. But a woman was involved, so she accused her father of poor judgement.

For Fatimah and Hadiyah who were filled with emptiness at the absence of their father, the process of adjusting was painful . From 1999 (when their father left for Saudi) to 2009 (the time I interviewed them), the parent-child emotional support was solely from their mother, Sarah. Now, they have appreciated the constancy of love among them - mother and four brothers. The remnants of their emotional struggle to endure the separation which culminated in divorce still brings memories of "bad times". Fatimah said:

Sa among kalisod kay wala na si Tatay, nakita ug nabati namo ang pagpaningkamot ni Nanay... ang iyang pag sakripisyon dili lalim. Si Tatay padala lang og kwarta pero si Nanay kauban namo sa tanang panahon.

[Life was hard, very hard for us when dad left us, but we also appreciated mum's sacrifices for us... We could never repay her back... Dad sends us money but it's mum who is with us all the time.]

Aminah: The case of Mother Separation. Like Hadiyah, Aminah experienced separation when she was seven years old. While Fatimah and Hadiyah were separated from their father, Aminah's case was different. It was her mother, who abandoned the family. Until now, Aminah could not come to grips with her mother's action nor of her father's silence on what was going on at that time. During the ten-year separation from her mother, a number of intervening events made her more confused yet at the same time, they resulted in some superficial recovery.

Aminah, the younger of two siblings, began her story by a vivid description of that ominous morning when she had the last glimpse of her mother. Aminah described the feeling as strange and likened it to the disengagement of a newly born from its umbilical cord. 
Although she could not perfectly remember the exact day, the image of her mother looking forlorn, embracing her tightly, and kissing her was imprinted in her memory. Because her mother was dressed as if she was going on a trip, Aminah asked, "Where are you going, mother?" There was no answer, instead, she kissed Aminah one more time, looked Aminah in the eye, and said, "Be a good girl. I will be missing you." This scene is common in melodramas on television. Aminah who tried to look unaffected started to sob towards the end of her narration.

Aminah kept on repeating the word "confused" because for nine years, she did not hear anything from her mother except that she was in the United States. A paternal aunt took care of Aminah and her older sister, Laila. Her father was very secretive about that issue. Every time she inquired about her mother's whereabouts, he would unnecessarily flare up. Eventually, her parental resource was close to nil because she could neither talk to her aunt nor to her father. Aminah's confusion was evident when she confessed: "I am deeply troubled why my mother left us because nobody explained the reason." She added that she couldn't think clearly." This "confusion" affected her personal and emotional development. Aminah further admitted that:

The family was disorganized. I was confused whom to "believe"... mother or father. I stayed with my father for nine years, but when my mother arrived from overseas, she wanted me to stay with her. Both of them had different versions why the family was broken.

Probing into her concept of family, Aminah smiled shyly. According to her, she has "two" families. Five years after her mother left, her father remarried and had children whom she adored. Her stepmother was kind to her and to some extent, became like a mother. She was longing for a real family, and she became attached to her stepmother and the three children. Thus, even though she is now living with her mother and older sister, she always spent her weekends with her father's second family. Although Aminah considered her stepmother whom she calls aunty to be strict, she finds solace with them, especially with her younger siblings. A highlight from Aminah's experience is that although she is a product of a 
broken family, she did not only give me insights on the effects of separation but also offer a different view on second families.

Karima's “Intact" Parents. In the previous discussion, Fatimah, Hadiyah, and Aminah traced the separation from either parent as the key factor of their emotional predicament. In Karima's case, however, both parents did not leave her and her two younger brothers, Abdul the elder, and Omar, the youngest and mentally handicapped. However, the initial reactions showed a similar pattern. Based on Karima's account, her parents were a typical married couple, so she and her brothers grew up in a normal familial relationship with both parents doing the routines: mother stays at home, father goes to work, and children go to school. Since her father is a businessman, she was used to his absence from time to time. All their needs were provided for, and she never imagined that one day, she would hear the dreaded word, "divorce" from her mother. Karima learned about her parents' divorce six years ago when she was 15 years old. Calling to mind how she reacted to the news, Karima said she told her mother:

It's so unfair, I never thought you will separate...I never heard you quarrelling because it seems everything was fine between you... How did it happen and why are you making such a decision?

Apparently, Karima had no inkling of the marital problems of her parents. Even the way she recited the scenes of that day revealed her innocence. Leaning towards the researcher and taking a deep breath, she recalled the day her mother disclosed the divorce by saying, "Your father would not be living with us anymore." Karima described her feelings as "upset, shocked, disappointed, and frustrated."

Karima clarified that it was almost eight o'clock in the morning. Like all other mornings, her mother was in the kitchen, while she and Abdul were preparing for school. When breakfast was ready, her mother called to them that it was time to eat,or else they would be late. Since the nature of her father's work explained his absence with the family at breakfast time, she ignored it. As soon as they were ready to leave the house, she stood at the corner, waiting for her mother who dressed up to take them to school. When she saw her 
mother going out of the room, she looked at her mother. Suddenly, she blurted out: "Mom, when is dad coming home? "' Immediately, her mother's face blushed and she looked tonguetied. After a while, her mother moved to her side and held her so tightly, and said, "Your father and I are already divorced... for more than a month now. "

Disentangling herself from her mother's embrace, Karima shrieked like a young kitten that was unintentionally stepped on by its mother. She was uncontrollable - shouting and cursing in her native language. Her mother made an effort to calm her down, and both of them were in tears. She ushered Karima to the living room, softly combed her long and curly hair, and slowly explained that the decision was not easy. However, both of them agreed because it was the last recourse. The estrangement between Karima's parents did not stop her father from seeing Karima and her younger brothers. A year after the divorce, her mother remarried. The stepfather stayed in their house, but the marriage did not last long. As for her father, Karima said he has another family now, and the relationship between him and her mother is no longer antagonistic.

The initial reactions of Fatimah, Hadiyah, Aminah, and Karima on their parents' divorce varied in terms of intensity, but their accounts were self-revelatory of emotional trauma. In the succeeding discussion, the next group of participants is emphasized based on their heightened reactions, which Fatimah, Hadiyah, Aminah, and Karima insinuated but failed to directly express in their accounts.

\section{Heightened Reactions: Anger, Blame, Rebellion, and Hatred}

Children of divorced parents tend to create distance from their parents in many ways, and experts in counselling and psychology view this as a form of defiance. Parents who go through a rough divorce seldom inform their children about it. When children learn that their parents are no longer living together in one house, the initial reactions are generally that of disbelief, frustration, and sadness. Depending on the support mechanism that operates (i.e. a strong mother fills up the gap of the father's absence, the father extends financial support, 
maintains the communication line open, or visits the children, the grandparents on either side extend emotional support, etc.), children still hold a grudge against their parents.

In this second sub theme, the lived experiences of Nasheeda, Hashim and Ahmad on parental divorce are discussed. The effects of divorce are often hard to comprehend, but the narratives of these three participants reveal strong emotions of anger and hatred.

The Father's Illicit Affair. Among the participants who had a strong personality was Nasheeda. Her parents are relatively well-off, but her father is occupied with his outstation business. Despite this arrangement, she and her twin sister and their younger siblings, a girl and a boy live quite comfortably. Unlike her twin sister, Nasheeda loves going out with friends and do some silly things that are uncharacteristic for girls, or for a Muslim girl.

Nasheeda was initially hesitant about her parent's divorce. Later she said, "There was another woman, very young, just a bit older than I am." Her mother had queried her father about some "mysterious" text messages on his phone. At first, the husband denied all the allegations of having an affair. One day, her father brought home a girl in her twenties and announced to the family, saying: "I am going to marry her." Nasheeda wanted to make a scene with the girl, but she didn't. She looked at her father with disgust, went to her room, and locked it. She cried bitterly, and kept on saying that she hated her father. After that incident, her father left the house and never came back. Later, her mother told her that divorce was on its way.

Nasheeda's relationship with her father deteriorated. She ignored his calls, and instead of confiding in her mother, she became morose. As Nasheeda recalled her mother's attempts to heal her pain and hatred, I could hardly hear what she was saying. The effect of her father's infidelity was so intense.

I love my mother... I also pity her because of what dad did to her and to us. I hate him. Sometimes I wonder why dads are like that. He had no shame because he brought the girl in the house. That incident kept bothering me, you know... 
Although she had no misgivings against her mother, she ended up having behavioural problems that affected her relationship with her mother. At the end, her mother gave up, moved her to another university, and asked her sister-in-law to take care of her. Nasheeda is now living with her aunt, but she also visits her mother and sister on weekends.

Parents'Abandonment. Another narration on how divorce incited negative reactions is that of Hashim whose parents divorced when he was fourteen. Hashim is the eldest child among the eight children, four boys and four girls. The divorce happened when he was only fourteen years old. As the eldest child, he described it as "tough, hurting, and unfair" to him and his siblings. He also questioned on why they have to suffer from their parent's marital problem. Leaning on his chair, legs crossed, taking a long deep breath, Hashim narrated the incident which later led to divorce.

It just happened that one day, both of my parents left the house. I thought they were just out, but night came and I was alone with my seven siblings. The following day, I brought all my siblings to my maternal grandmother's house... We stayed there for a week. Then my father came and talked to my grandmother. The week became a month...Since then, our grandmother took the responsibility of raising us. It was unfair...

At fourteen, Hashim felt the impact of his parents' utter neglect. As the eldest son, the impact of his parents' separation was "tough" because the younger ones kept asking him questions that he could not answer. What touched him most was that the youngest was only four years old. Five of them were going to school, and the grandmother's income as a trader in pasar malam (night market) was not enough. Deep in his heart, he wanted to yell at his parents for abandoning innocent lives. His siblings complained to him that they were hungry, that they miss their father and mother, and that they wanted to buy notebooks and other things. Hashim expressed his feelings saying:

Silently, I accused my parents as irresponsible for leaving us. I blamed them because they have no right to leave us under the care of grandmother. How could she feed eight hungry mouths and provide our school needs? We managed, but life was very very tough.

Hashim also mentioned that it took him time to reconcile with his parents. For years, he treated his parents as if they did not exist. He refused to talk to them even in the presence 
of his grandmother. Because he knew the grandmother needed assistance, Hashim quit school for two years. He helped her sell goods in the night market. Although Hashim suffered the brunt of his parents' abandonment, he has also learned to forgive them. Now, Hashim and his siblings are still living with their grandmother. When I inquired about his parents, Hashim said:

My parents live separately. None of them remarried. Looking back, I believe they are just two individuals who couldn't withstand each other's inadequacies. I blamed them before, but now, I look at life positively because my faith in Allah is strong.

Irresponsible Father. The disruption of the family usually begins when parents have marital conflict. Because parents are role models to their children, they hide their quarrels from them. As a result, when their differences are irreconcilable, they divorce. In the case of Ahmad, he was a witness to his father's physical abuse towards his mother. Ahmad has two older sisters and a younger brother, making him the eldest boy in the family. According to him:

I grew up with an irresponsible father... I think he has not really understood his role as father and husband. He loved to spend time with his friends... He had no permanent job because he didn't like people to tell him what to do. My mother has a business...

Ahmad's recollection of the night his father left them was bitter. He remembered hearing his parents arguing in their room. Because they were raising their voices, his sisters who were in the kitchen cried. Ahmad was in the living room with his younger brother. At first Ahmad said to himself, "It's better for him (father) to go rather than hurt mother." But his sisters were crying louder and louder, so he joined them. Then the house was in chaos. At this point, Ahmad sighed. He looked at me with misty eyes. I told him to take a deep breath and if he found the experience too painful, he could stop. Instead, he continued:

I saw my father carrying a bag. He was going out of the room followed by mother. I was certain he was ready to leave us. My sisters were begging him not to go, but instead, he ignored their plea. He looked at my mother, and in a threatening voice warned her, "I am leaving this house and all the children to you! From now on, you take all the responsibility. I don't care what will happen to all of you!" That night, he left us... 
Ahmad did not have a happy childhood, but he tried to be a good son to his mother. After the divorce, Ahmad said that his mother and siblings were happier than when the father was around. He attributed this to his father's weak disposition and attitude towards Islam.

\section{Continuing Impact of Divorce}

Based on the lived experiences shared by the participants on parental divorce, a common pattern emerged. Four of them (the sisters Fatimah and Hadiyah, Karima, and Ahmad) showed sympathy with their mothers while three participants (Aminah, Nasheeda, and Hashim) were quite ambivalent to either or both parents. However, five of them (Fatimah and Hadiyah, Karima, Nasheeda, and Ahmad) lived with their mothers immediately after the divorce. On the other hand, Karima stayed with her paternal aunt while Hashim, who was abandoned by his parents, brought his siblings to his maternal grandmother's house. In terms of father-child relationship, some expressed hatred, frustration, and disappointment while others had fond memories.

Generally, in the study of psychology, we learn that experiences in childhood have long-term consequences that may filter into later stages of the life course. The first sub-theme related to painful memories discusses the continuing impact of divorce to children. These include lingering feelings of sadness, longing, worry and regret. The prevailing effects of divorce were apparently confirmed by the participants of this study. The past keeps coming back because with the pain of losing either one of their parents, or in the case of Hashim, of both parents, some memories were happy and fulfilling. Generally, all the participants longed for a happy family, and they also expressed deep regret of having been neglected when their parents decided to separate or divorce.

\section{Externalizing Effects of Parental Divorce}


Divorce affects children in a variety of ways, many of which can cause long term problems if not recognized and dealt with immediately. Some children can encounter emotional problems such as withdrawing into a shell or becoming aggressive. They can end up suffering from depression or developing behavioural problems. At school teachers may notice a change in the children's relationships with their friends as well as their poor performance in the class. In many cases, even if children are relieved from their parents' marital tension, they still harbour some grudges against them. To explore the lived experiences of the participants in terms of behavioural aspects of parental divorce, the discussion is narrowed to two sub-themes, namely, providing various risks and eliciting positive effects.

Numerous studies have shown that children of parental divorce are badly damaged. This study, has found various risks experienced by the participants. Precisely there are many risks involved in parental divorce. However, from the accounts of the seven respondents, the risks are categorized into two broad concepts. The first is social detachment and the second is poor academic performance. An example of social detachment is the experience of Fatimah whose account offers a broad lens within the phenomenon of parental divorce. She pointed out that her parents' separation made her reluctant to make new friends or even to be with the other girls in school. She says:

Nawala pud akong gana sa pakig-amiga, ug mura man ko og dili na ganahan makig kuyog pa kang bisan kinsa, ug wala na jud ko mo "participate" pa sa klase. Gina sulat lang nako akong mga "answers", ug wala na ko'y daghan nga amiga. Nawad-an ko ug pag-tuo sa akong kaugalingon. Ug kung naa may mga programs sa eskwelahan, dili ko moapil ka yang akong hun-huna dili nako makaya.

[...I lost the motivation to make friends and I stayed away for the other girls. I stopped participating in my class. Even if I knew the answers, I just wrote them in my notebook. It seemed like I lost my voice in front of people. Perhaps my friends took it as negative, so I gradually lost some of them. My self confidence was very low. As a result, I intentionally skipped school activities...]

Karima's potential to excel in sports was shattered by parental divorce. When her parents' divorced, her passion for tennis diminished, and she retreated from the sport she had not only enjoyed but even excelled in since she was five years old: 
I am the only daughter and I know my father used to adore me. Every weekend, he would take me to the nearest tennis court. I was five years old when he asked me to hold a racket. Since then he was coach. When he left, I felt frustrated. I sort of hated him for divorcing mum. Slowly, I began to dislike tennis. My self esteem was very low.

Every time Karima mentions the word tennis, her voice betrays the silent cry of a rejected child. Such rejection was later transformed into silence for more than a year. Karima refused to talk to her father who also hesitated to initiate the move to reconcile with her. Her relationship with him has gradually improved over the years.

Another concrete behavioural effect of parental divorce on the seven participants was their poor performance in school. Since much of the participants' post-divorce adjustment is dependent on the quality of their relationship with each parent before the divorce, the lived experiences also vary. To illustrate this, we shall use the experiences of Hadiyah, Fatimah, and Aminah.

Hadiyah shared that her parents' divorce initially had an adverse impact on her studies:

Wala lang jud ko'y gana sa school, sukad akong Tatay, nga close nako wala sa balay...murag wala man gud sya aron malipay kung naa ko'y ma "achieve". Nahiubos man gud ko kaayo sa iyang pag-lakaw ug "discouraged" sa iyang gihimo kang Nanay. Tinuod, bisan karon cge gihapon ko'g hunahuna ana.

[When dad was no longer around, I also didn't feel like going to school. Since I was very close to him, I felt that my achievement made him happy and that it was solely for him. I was really hurt when he left, and I was disheartened of what he did to mum. The truth is, until now, I keep on asking why dad left us.] Although Fatimah was a smart girl who used to excel in school, after her father left,

things changed. Her overwhelming sadness resulted in loss of focus. She described her behaviour as follows:

Sa gihapon nga akong ginahimo kada ting-klase, akong bag puno sa libro ug uban nga kailangan sa eskwelahan. Grade six ko ato pag-bulag nila Nanay ug Tatay. Pag-abut nako sa eskwelahan, ga huna-huna ko unsa akong maka-ot karon adlawa...molingkod ko duol sa bintana, samtang ga tan-aw sa akong mga classmates ug ga paningkamot nga gahatag ug attention sa akong teacher. Molabay pila ka mga minuto, akong na realize wala ko'y nadungog o nasabtan kung unsa ang gi-explain sa akong teacher. Gahangad ra ko sa taas sa atop sa eskwelahan, gapang-it sa akong lapis, ug gatan-aw nga wala sulod akong huna-huna. 
[I regularly went to school like a typical student, my school bag full of books and other stuff. I was in sixth grade when the divorce happened. As soon as I arrived in the classroom, I tried to set my mind of the things I would learn for the day... sitting near the window, I looked at my classmates and pretended that I was listening to the teacher. After awhile, I came to my senses that I actually didn't hear nor understand what was going on. I stared blankly at the ceiling while nibbling my pencil. I was completely out of my wits. ]

Fatimah's words revealed a confused state of mind. Her thoughts were disorganized due to lapses of what happened in the past and what she should do in the present. Consequently, her emotions affected her grades, and she was dropped in the honour's list.

She further elaborated:

Tungod sa kulang sa akong concentration, akong grade ni mubo jud. Mag-sige ra man ko ug huna-huna sa akong Tatay, ug ga pangutana sa akong kaugalingon nganong iya ning gihimo sa amo. Ga hilak ko sa among classroom samtang naka dungog akong mga classmates sa akong pag-hilak. Ga cover ra ko sa panyo ug tawagon sa akong mga classmates akong manghud nga tua sa pikas nga classroom...

[Because I could not concentrate in the class, my grades tremendously decreased. I kept on asking why dad did such a thing to us. Every time this question came to my mind, I couldn't help myself but cry in the classroom. I covered my face with a handkerchief so that my classmates would not hear me. But they did, and they called my sister who was in the next room.]

Aminah grew up without a mother. Unlike the other children whose fathers left after divorce, she described her experience as follows:

I grew up without my mother, since she was the one who left the family... I was really confused and troubled. In school I always thought I was inferior because I was behind my classmates. I was aloof... would not initiate to make friends. They knew me as a quiet person, but actually, I was thinking of so many things...

From Aminah's account, I sensed that she was hiding an intense feeling against her mother. Indirectly, she was blaming her for causing the separation or divorce. She became a loner and felt inferior to her classmates.

\section{Synthesis Of The Participants' Lived Experiences}

In understanding and exploring the phenomenon of parental divorce based on the disclosures or narratives of the seven participants, I employed the phenomenological reduction of assigning three frames. The first probes into the internal effects; the second explicates the 
external effects; the third and last elucidates the mediating effects. Reducing lived experiences means two things: taking the participants' accounts as currently appearing in their consciousness, and interpreting their accounts not as what they claimed, but to explore further and draw their experiences into the phenomenon. To make this possible, I used my imaginative variation to discover the essential characteristics of parental divorce as the phenomenon being investigated. This resulted in the sub-themes of individual characterization, highlighting their emotions and behaviours, and subsequently, making each a unique individual who suffers the effects of the same phenomenon - parental divorce. Reducing their lived experiences into individual vignettes facilitates the richness of the recollected event, moment, or musing with the social context of divorce.

In the first phenomenological frame on internalizing effects of divorce, the theme was inciting negative reaction. The purpose was to determine the causes of divorce, which were reduced to six narratives: Father Separation; Mother Separation; Intact Parents; The Father's Illicit Affair; Parents' Abandonment; and Irresponsible Father. From these smaller frames, the lives of the seven participants were revisited and relived as appearing in the present time. As the investigation becomes more engaged, the second theme was continuing impact of divorce. The aim was to explain the long term effects of divorce. For this, another six narratives were used to describe the participants: Karima and her coach; Aminah and her Mother; Hashim and his parents; Ahmad and his father; and finally, Nasheeda: The Rebellious.

In the second phenomenological frame on externalizing effects of divorce, the first theme was providing risks. The objective was to demonstrate how emotions manifest into actions or behaviours. Under this, I portrayed them into six narratives: The Island within Fatimah; Self Exile from Sports; I am Unworthy; Hadiyah: The Underachiever; I Lost My Concentration; and Aminah: The Loner. The second theme on eliciting positive effects discussed the redeeming aspect of divorce. Six narratives were used: Karima: The Big Sister; 
Fatimah: The Second Mother; Hashim: The Big Brother; Ahmad: The Apprentice; Karima: The Unsung Heroine; and Hashim: Making a Choice.

In the third and last phenomenological frame on mediating effects of divorce, the first theme was coping and healing strategy. The aim was to understand the influence of Islam in their lived experiences after parental divorce. I described the participants in four narratives: Mother: The Light of the Family; Self-Criticism; Hashim and His Faith; and Ahmad and Karima. The second theme on perceptions on family and marriage explained the participants' views on family and marriage. For this theme, six narratives were composed: Happiness Despite Financial Difficulties; Presence of Both Parents; Father as the Head; Responsible and Just Parenting; Unfounded Fear; and Empowering the Self.

The various narratives emerged from the participants lived experiences, and understanding each individual who had been through the same phenomenon was the central feature of the interpretation. Their accounts showed that different experiences shaped their own lives, and as a researcher and counsellor, I tried to immerse myself in their way of knowing, and the sub-themes I deduced from their disclosures indicated the many facets of understanding and exploring phenomenon of parental divorce.

\section{DISCUSSION:THE SIX CONSTRUCTS OF PARENTAL DIVORCE}

The disclosures of the participants on parental divorce are embedded in the phenomenological frames, namely internalizing effects, externalizing effects, and mediating effects. Using the sociological concept of family as the basic unit of society presupposes that once the unit disintegrates (i.e. divorce as cause), the members suffer fractures and they need healing of their wounds. Extending this disintegration to society would result in some cracks in the system which in the first place allows or legitimizes divorce. In fact, Jaffe (1991) stressed that in the United States alone, the acceptance rate of divorce reached 50\%, and he concluded that the increase was a reflection of a society where many couples went to court to terminate their marriages. He further predicted in 1991 that by the year 2000, children of divorce will be living either with their stepfamilies or in single parent families. After almost a decade, the 
figure would likely increase, with children suffering from emotional and behavioural problems (Amato, 1994; Derdyn 1994; Hetherington \& Kelly, 2002; Stanley-Hagan, 2002; and Harvey \& Fine, 2004). However, an earlier study had already stated that the effects of divorce on children vary and that each child should be taken as a distinct case (Wallerstein, 1983).

Following Wallerstein's notion of the effect on the child of divorce, the six constructs provide insights on how to counsel children of divorce. In the absence of empirical studies on the effects of divorce on Muslim children and adolescents, the constructs also form the foundation of the Islamic counselling model. Since the effects of divorce on children have long been established to manifest in early adulthood in the areas of intimacy (Johnson \& Thomas, 1996), more specifically on establishing relationships, counselling would help to "facilitate toward their progression toward healthier intimate relationships" (Conway, Christensen \& Herlihy, 2003: 371). For instance, some participants in this study have developed the fear of getting married, which if not mediated through counselling, may lead to marital failure. Hall (2008:1439) believed that "how people perceive or understand marriage are related to marital functioning," and previous research reported findings that support the premise. It was found that the spouses who experienced more marital distress and less martial satisfaction were those who had unrealistic or dysfunctional expectations and beliefs about marital roles, conflict, happiness, and other marital issues (Hall, 2008; citing Bradbury \& Fincham, 1993 Eidel \& Epstein, 1982).

\section{Causes Of Divorce And Its Continuing Impact}

In viewing the family as an emotional unit, Bowen (1985) focused on the nuclear family's defined boundaries of harmony and discordance (Kerr, 1981). How these two operate was further expounded on the counterbalancing of life forces such as individuality and togetherness (Kerr and Bowen, 1988). Thus, the family's function as a unitary whole is governed by action and reaction. When anxiety in the system increases, there is heightened reactivity, and the pressure for togetherness increases as well. According to Kerr, "the greater 
the fusion, the more difficulty coping with or keeping emotions in balance" (1981:238) and the binding sense of responsibility for the well-being of others or the assumption that someone is responsible for one's own well-being result in impaired ability to keep the emotions at bay. Thus, when parents have marital conflict, other members are also affected, and the family as an emotional unit becomes dysfunctional.

In this study, the participants are not very critical about marital conflict as the cause of their parents' divorce. However, going through their narratives, only Nasheeda, Karima, and Ahmad mentioned that their parents had marital conflict. Even then, the extent of their knowledge was very superficial. For instance, in Nasheeda's narrative, she gave an alibi of her vices, saying that since her parents could not solve their own problems, why would she listen to their advice? This suggests that the cause of her parents' divorce was marital conflict and her father's illicit affair with a younger woman. Similarly, Karima was aware that her parents had differences. When she knew about the divorce, she was shocked, saying "I thought they have already fixed their problem". Nasheeda might have heard them arguing or observed that something was wrong between her parents; however, she did not elaborate. Lastly in Ahmad's case, he was "happy" about the divorce because of his father's physical abuse towards his mother. This means that divorce has eliminated the cause of his mother's suffering, yet left an indefinable feeling of "the absence of the nonresidential parent" (Vandevalk et al., 2008), Ahmad's father.

Although marital conflict may account for the cause of divorce (i.e. the cases mentioned earlier), another concept that has emerged from the narratives is parental absence perspective (Amato, 1993; Hetherington et al., 1998). Again, this assumption is traced in the emotional cohesiveness of the family characterized by a child's attachment to both parents, one parent, or any person who provides him or her security, warmth, love, sympathy, and other positive feelings (Bowlby 1969). Apparently, when the source of the attachment is absent, children generally suffer seperation anxiety. Let me clarify this by discussing the four remaining participants' view on the cause of their parents' divorce. 
The sisters Fatimah and Hadiyah experienced separation from their father who went to Saudi Arabia for employment. Although both of them were attached to him, the greater impact of his absence was felt by Hadiyah, the younger sister. The emotional intensity of the loss between them differed because Fatimah later confessed that as the eldest, her responsibility was to "balance the emotional scale" so that the family can survive despite the father's absence. As noted by (Emery et al., 1992), children had to adjust when there are disruptions in the emotional security. But what happens when it is the mother who leaves the domicile? In a study conducted by Kapinus (2004), she emphasized that parents' attitudes are related to offspring's attitudes on a variety of issues, including for instance, views regarding various facets of family life. A number of literature (Acock \& Bengtson, 1980; Bachman, Johnson, \& O’Malley, 1987; Glass, Bengston, \& Dunham, 1986) further support parents' effect on issues including political affiliation and religious beliefs. Moreover, they suggested that 'both mothers' attitude toward divorce and mothers' marital experiences influence young adults' perceptions on divorce" (Kapinus 2008: 113). This helps explain why Fatimah's family remained united because her mother did not wallow in being dejected by her husband. Instead, she appealed for their support (Fatimah and Hadiyah). In the case of Aminah, her mother's absence for ten years left her with no one to hold on to for emotional security. The mother-child relationship totally diminished, so when her mother returned, Aminah could not find a way to connect with her. While her mother capitalized on her maternal right in an attempt perhaps to assert that she is still the mother who should take care of her, it could never be erased in Aminah's psyche the disruption of the attachment. Thus, her mother's absence has influenced her perception on family and marriage.

Hashim's case is worse because two parents were absent, yet he was able to transform the abandonment into a positive force. This can be explained through "sibling position" (Kerr, 1981). Hashim as the eldest had to perform functional expectation because failure to do it would destroy the lives of his seven younger siblings. He became the surrogate parent, and the burden was too heavy. His negative view on marriage is congruent with the findings of 
Chase-Lansdale \& Hetherington (1990) that the consequences of divorce were worse for boys than girls. The longitudinal studies of Amato and Rodgers (1999) reported that parental divorce and conditions surrounding the divorce were likely to affect daughters' marital outcomes more negatively that those of sons. Moreover, in the study of Davies (1999), it was found that family environment continues to be of crucial importance throughout the adolescence and young adulthood because of the important role of psychological functioning for youngster's daily lives. Thus, the presence of both parents is very crucial.

The disappearance of either one parent would bring psychological problems (Laufer \& Laufer, 1984). One aspect of the family that has been steadily found to affect the emotional adjustment of adolescents is the quality and stability of their parents' marriage (Amato \& Keith, 1991a, Cherlin et al., 1991; Emery, Finchman, \& Cummings, 1992). Subsequently, numerous studies have shown that youngsters growing up in families with a happy, harmonious parental relationship experience fewer problems and have a higher well-being than those from divorced or maritally distressed families (Amato, Loomis, \& Booth, 1995).

The continuing impact of divorce reveals notable patterns of nostalgia, a melancholic disclosure of happy and tender images of either parent before the divorce. This is evident in the lived experiences of the sisters Fatimah and Hadiyah (longing for their father's presence), Karima (wishing her father is around so they could be buddies in tennis), Aminah (yearning for a "real" mother for ten years), Ahmad (wishing he grew up with a responsible father), and Hashim (remembering his father taking him to pray in the mosque). These are the common innocent pleas of children of divorce across races and cultures. In contrast, Nasheeda, the rebellious kid, was less compassionate of her father's infidelity. Her consistent portrayal of herself was further revealed in her perception of marriage. According to her, she has a boyfriend now and her doubts of constancy were somehow resolved. However, should there be a reason for her and her partner to divorce, she would be the one to initiate it. With a biting remark, she said she does not want to be financially dependent on her husband. The same findings were reported by Laumann-Billings and Emery who (2000) conducted a ten-year 
longitudinal research on the effects of divorce on children. They stressed that children had continuing pain and distress on their parents' divorces and described more painful childhood feelings and experiences compared to those in married families.

Harvey, Weber, \& Orbuch, (1990) said that a major loss, such as marital separation and divorce, initially diminishes the self. Such an event may reduce one's dignity, will, or resources. By definition, the breakup of a close relationship, takes a psychological and physical toll on the principal parties concerned, including any children involved. Similarly, when children experience heightened anxiety, they manifest in symptom development (Kerr 1981). For some children, their ability to distinguish thoughts from feelings and to choose between being guided by one's intellect or one's emotions, result in differentiation. According to Kerr (1981) as an individual member of the family, the child is bound to adhere to his or her own inner convictions, regardless of other's support or to refrain from pressuring others to change their beliefs and actions. Because differentiation describes the measure of ratio of energy tied in relationship (Heras, 2001) said that experts on psychotherapy use the "scale of differentiation" which was developed by Bowen (1985). In this study, differentiation is subsumed in the two constructs: self-assessment and roles played.

The six participants confessed that their parents' separation and/or divorce affected their performance in school. For example, Fatimah felt like an outcast among classmates resulting in loss of concentration and decrease in marks. Hadiyah, Fatimah's younger sister, further retreated into the background. She lost her motivation to study and got very low grades. On the other hand, Aminah's behaviour of extreme confusion resulted in not mixing with others. She became an anti-social and felt she could not compete with others. Another participant, Hashim, described himself as extremely shy. These behavioral problems are also suggested in other studies (Nair \& Murray, 2005; O’Brien et al., 1997; Spigelman \& Spigelman, 1991) that underscored the painful experience of children who exhibited poor behaviour, lower academic achievement, disengagement, and alienation. Moreover, according to Juvonen et al. (2004), children of divorce also demonstrate social-emotional difficulties, 
motivational problems and low achievement, lack of interest, negative attitude towards school, social alienation and disengagement. In terms of younger children, Amato and Keith (1991) found them reacting negatively, feeling confused and wondering what their relationship is to the parent who is no longer living in the home.

Deterioration in the parenting of both custodial and non-custodial and residential parents for the first several years after separation is a common stressor (Hetherington, 1999; Wallerstein \& Kelly, 1980). Parents are preoccupied with their own emotional responses to divorce and the demands of integrating single parenting with work and social needs are stressful. Some children and adolescents become the sole emotional support for their distraught and needy parents. Because of the interconnectedness of emotional force that binds the family as well as the pressure of sibling position, four participants performed what Jurkovic (1997) called parentification, which is defined as taking the roles generally played by parents. A good case is Fatimah. After the family's separation from her father, she became the "second" mother and thereby forcing herself to motherly role.

Karima's mother is strong, but the absence of the husband has impaired the cohesion of the family. Karima has two younger brothers; one of them is mentally handicapped. This is also one reason why the mother needs somebody to support her, so Karima assumed the role of a big sister. On the part of the male participants, Hashim became "parentified" as a big brother, while Ahmad assisted his mother in their mini mart. To some extent, parentification explains the roles played by the participants to maintain the emotional balance in the family that is bounded by individuality and togetherness (Bowen 1985). This means that the participants are able to make the necessary adjustment while they are in the midst of redefining their own personalities. According to Amato and Keith (1997), cited by Vandervalk et al. (2008), the emotional adjustment of adolescents is "lower in adolescent girls as compared to adolescent boys" (Vandelvalk et al., 2008: 311), but as shown in the different roles portrayed by Fatimah, Karima, Ahmad, and Hashim, their family environment and the 
IIUM Journal of Educational Studies, 1:1 (2013) 55-97

Copyright (C) IIUM Press

degree of previous attachment to either parent are the influencing factors of their parentification.

\section{Islamic Values And Perceptions On Family And Marriage}

This is an important area in research inasmuch as there are voluminous studies on divorce. That a child's psycho-social, academic, and adjustment problems are related to how parental divorce affects him or her (Amato and Keith, Hetherington, Cherlin, Wolfinger, ) Although previous studies reveal how divorce affects the children, it failed to examine or explore the spiritual dimension in coping with the experience. It makes this study significant in that it tries to examine how Islam as the participant's religion helped them cope with the experience. This is to emphasize further that for the Muslims their lives are in the bonds of Islam in every aspect. Basically, this study explored and provided a depth of understanding of:

a. the adolescents experiences and perceptions of parental divorce;

b. the effects of divorce on their well-being;

c. their perceptions of marriage;

d. whether Islam as their religion influenced their coping experience.

The narrations of Fatimah presents an understanding that prayers helped them cope or perhaps gave her the strength to handle the marital conflict her parents suffered. As a Muslim from religious parents Islam has been taught to them at an early age. It helped her to cope and specifically she mentioned how her mother also prayed fervently to be able to cope up with the incident. An important dimension that this study wanted to explore is how Islam as the religion of the participants help them cope with the situation. Considered to be the first to investigate Muslim children's experiences on parental divorce, the highlight of this study is to see how being Muslim makes them resilient to their parent's divorce.

Different levels of coping with the Islamic religion were evident throughout the sample. Children who are brought up closely with the teachings of Islam have found refuge in their Islamic faith. For other participants, they do become responsible and matured too, but 
their narration was emphasized on becoming more religious. Parents are always said to be influential on their children behaviour and moulding of their attitudes or characteristics. From the interview, there are participants who shared that because their mother was remarkably engaged in religious pursuits, they too become like their mother.

Fatimah and Hadiyah were the participants referred to here who became religious due to the experience. Even before that incident of divorce, they both were attending Madrasah required by their mother, being a former Madrasah student herself. Hence, when it happened, according to their narrations, their mother encouraged them to learn more of the Holy Qur'an, increase their prayers and other religious duties. Eventually, it allowed them to be spirituayl strong enough to be able to cope with the problem.

\section{Implications For Counseling}

The need for counseling has existed at all times, but the situations and various problems people face today have intensified this need considerably (Shetzer, et al. 1974). Cases of divorce intensify the need for school counseling. Literature and studies reveal the devastating and lasting effects of parental divorce. That children who are victims became problematic in personal, emotional, and social aspects (Amato, 2004; Amato \& Booth, 1996; Hetherington, 1978). It is an alarming fact that divorce really affects the well-being of children.

Moreover, programmes and or services in counseling should grow out of the needs of students or clients. The program therefore should be flexible in all its aspects. Counseling should be continuous and should serve all-the deviate as well as the normal. It should be concerned with the whole individual in his total environment, but with specific needs and problems.

In this study, the children of divorce are in need of a programme that could assist them with the situation. Therefore, Muslim practitioners should implement a programme especially for the children of divorced parents.

It is important to note that by understanding the factors related to the academic and interpersonal relationship problems often experienced by children of divorce, counselors can 
begin to generate interventions and treatment strategies specific to the needs of these children. To start with such a move Hage \& Nosanow (2000) developed a model for group work with young adults from divorced families by using a psychoeducational group interreaction ?. Based on their awareness of the long-term issues of parental divorce, Hage and Nosanow focused on topics such as assertiveness, communication skills, self-esteem, trust, intimacy, and enduring significant relationships. Although this approach provides an example for counselors who work with individuals in a group setting, it also serves as an example for family and couple counselors. Similarly, this model could also be applied to Muslim clients, with a focus on Islamic perspective.

As another example, when working with children affected by divorce, group counseling could be conducted with specific attention to topics such as trust, intimacy, abandonment, loss, betrayal, commitment, communication, assertiveness, and self-esteem. Not only will this allow counselors to assist parents and children in understanding the ramifications of divorce, but to generate solutions to such relationship problems. Essentially, once identified, counselors can help these families shed ineffective behaviors and make healthier interpersonal relationship choices (Johnson \& Thomas, 1996).

As this study is participated in by Muslim clients, counseling sessions should provide group discussions that in Islam, though it is hated, it does allow divorce. Parents have the option about whether to go along with such distressing life situations or choose to file for a divorce for his/her sake and that of his/her children. On the other hand, as Muslims Islam protects all the rights of the members of the family. And one's faith, acceptance and submission is also crucial at this point of their lives.

Furthermore, Muslim counselors can assist divorced parents in understanding the effect of their behaviour and interactions on their children now and as they become adults. It is essential for parents to understand and help their children move through the multiple and tumultuous transitions that accompany divorce. Parents need to be aware of their behaviour 
between one another and toward their children. Ideally, parents create new civil relationships with one another and work as a parental team as opposed to adversaries.

In addition to the above statement, counselors are advised to be aware of issues regarding differentiation when working with children from divorced families. Broadly speaking, it appears that children who experience divorce in their families attain a lower level of differentiation. As adolescents struggle with monumental decisions such as attending college, pursuing career options, and seeking intimate partners, their levels of differentiation may have a significant effect. Counselors are encouraged to validate the feelings aspect of their clients' decision-making style and also help their clients explore decisions from more objective stances. Processing the reasons that their clients are making decisions, especially reactive ones is invaluable in enhancing self-awareness and expanding options in more than one direction. Based on their experiences, young adults from divorced families may either attempt to imitate their parents' choices in mate selection or conversely, choose partners whom they presume to be very different from their parents.

In general, counselors who work with families after or during divorce are encouraged to recognize the effect of divorce on family members and to encourage those behaviors that moderate the effects of divorce. Suggested goals include working with families to decrease the amount of overt conflict and increase cohesion between family members. Counselors may achieve these goals by teaching family members effective conflict resolution skills assisting families in reorganizing their boundary structures and planning activities among members that recognize changes in boundaries while still enhancing interactions between newly formed subsystems. It is specifically advisable to work with young adults in forming separate but healthy relationships with each of their parents.

The second area probe in this study is the perception of the participants towards family, marriage and divorce. Having encountered with overwhelming experiences on their parents' separation and divorce, this part of the analysis will present the perceptions they should have towards marriage and divorce. 
The analysis is clustered into: 1.) Definitions of family, and 2.) Views on marriage. Under the definitions of family participants defined it as a.) Happines despite financial difficulties; b.) Presence of both parents; c.) Father as the Head; d.) Responsible and Just Parenting. On their views of marriage, participants viewed it as having e.) Unfounded Fear; f.) Empowering the self;

Participants perceived that being able to witness the struggle, suffering, and conflict of marital relationship that led to divorce of their parents, they developed unfounded fear that their marriage in the future might also end in marital dissolution. Out of eight participants, five of them have similar perceptions of fear.

The descriptive phenomenological method afforded participants the opportunity to talk about their experiences on parental divorce that on the inquiry of its effect the internalizing, externalizing and mediating effects are the common themes that emerged in the study. Thus, the aim of exploring their experiences was achieved in this study. By understanding what adolescents went through on their parent's separation, this study confirms previous researches on the lasting effects of divorce to children. Such as poor academic achievement (Amato, 2004), low-self-esteem (Hetherington, 1996), adjustment problems (Wallerstein, 2004)), depression, (Cherlin, 2002), However, with the prevailing negative effect, Cherlin (2002) claimed that parents' divorce brought some positive aspects to some children. As shared by one of the participants in this study, she commented: "It gave me early maturity and becoming more responsible". To substantiate, Wallerstein (2004) claims that the effects of divorce depends on the age, gender, personal maturity and the intensity of the marital conflict. However, as this study simply carried out an exploratoration on phenomenological inquiry, , it still contributes to the existing literature in the study on divorce and its effect to children. Taking an initial step in exploring the effects of divorce on Muslim adolescents. Zieman \& Baker-Randall (2000) considered adolescents see divorce as their parents' own problem and also see the institution of marriage as distrustful and unreliable, probably because of their cognitive maturity. 
Prior research has established findings of the effects of divorce on children. A good number of which were longitudinally done, investigating differences between children of divorced parentswith children from intact families (Gabardi, 1992), effects on divorced to offspring's attitude towards marriage, studies on differentiation (Rogers, 2002) divorce, and adolescents' intimate relationship. (Johnston, 1996)), But the context of the study was all in Western inquiries and none so far have investigated how divorce affects the Muslim experiences. There were similarities of findings in this study from previous researches. In fact the themes found in this study are akin to the findings of Amato (2004), Hetherington, (1996).

From the findings of this study it was found that parental divorce is emotionally distressing as described and narrated by the participants. They suffer poor social-adjustments, low self-esteem, and these findings are congruent with the work of Hetherington (1996); Wallerstein (2004); Amato (2004).

However, despite the distressing effects of divorce, the participants being Muslims somehow have turn to Islam as their religion to accept, submit and pray for assistance on coping with their problem. An interesting area for new research may be to investigate if polygamy as allowed in Islam increases the rates of divorce and how adult children perceived this

On the other hand, AbdulRaheem (1998) claims that the Muslim society has a great need for counseling, but that counseling should be consistent with the worldview of Islam. With this statement it is imperative to establish counseling programs tailored to the needs of the Muslim clients with emphasis on Islamic teachings and values. The creation of Islamic counseling is a must for a school so that Muslim children are oriented in Islamic counseling sessions, where their problems are addressed and solved by providing advice and coping suggestions according to the views of Islam.

Adolescents involved in divorce most certainly can benefit from counseling (Kazdin, 1993). As a counsellor and a Muslim, the experiences of Nasheeda, Karima, and Ahmad are 
no longer narratives of pain, disappointment, frustration, and hate simply because their parents decided to divorce. To elucidate this, let me cite the case of Ahmad. Counselling this boy who had witnessed his father's abuse using ready made formulas to heal his disillusioned image of a father who should love his family and pity of a mother who could just cry because of her husband's physical abuse no longer fits within the western model where women view domestic violence as a crime, and therefore, the perpetrators, upon conviction, deserved to be punished under the legal system. Although the Holy Qu'ran states that domestic violence is a transgression of Islamic principles on marriage, why did Ahmad's mother bear the pain? Or, how could a counsellor heal Ahmad's pain when his self-image as a child and a son has already been tarnished by his dim past? What Islamic counselling should be given to Ahmad?

Putting all these personal experiences in the context of Islamic counselling is not easy neither is counselling each one of them. I would like to expound this by citing Nasheeda's case. She is conscious of her "bad" conduct (i.e. disobeying her parents, hanging out with friends and going home very late, and smoking) because straight from her mouth she said, "I know I am a Muslim but my actions are not." What counselling strategy could draw her closer to her faith?

From the accounts stated above, I place my case of strengthening the Islamic counseling model which is a great job to be initiated by Muslim scholars, psychologists, counselors, and mental health professionals. It is high time that the development and establishment of Islamic counseling approaches to help Muslim clients.

\section{Summary and Conclusion}

As the frequency of divorce increases, so does the necessity for couple and family counselors especially Muslim counselors who are knowledgeable and skilled in helping those affected by divorce. Researchers and clinicians have responded to this need by providing empirically grounded information and treatment strategies specific to helping children deal with divorce. However, there has only been minimal coverage of the lifelong complications experienced by adult children of divorce specifically in the areas of interpersonal relationships. As parental 
IIUM Journal of Educational Studies, 1:1 (2013) 55-97

Copyright (C) IIUM Press

divorce in and of itself does not lead to adult problems in interpersonal relationships, it is of primary importance that couple and family counselors become more aware of the factors that contribute to the negative effect of divorce.

The effect of parental divorce on children has been established to be overwhelming. It is hoped that this study has provided information and description on the phenomenon on parental divorce among Muslim children.

\section{BIBLIOGRAPHY}

Abdulati, H. (1997). Islam in focus. Cairo, Egypt: El-Falah Publishing and Distribution.

Ainsworth, M.D.S. (1989). Attachments beyond infancy. USA: American Psychologist.

Ainsworth, M.D.S., Blehar, M.C., Waters, E., \& Wally, S. (1978). Patterns of attachment : Psychological study of the strange situation. Hillside, NJ: Erlbaum. .

Al-Attas, S.M. Naquib. (1977). Islam and secularism. K.L.: Muslim Youth Movement, Malaysia

Al-Attas, S.M. Naquib. (1993). The nature of man and the psychology of the human soul. Kuala Lumpur: ISTAC 
IIUM Journal of Educational Studies, 1:1 (2013) 55-97

Copyright (C) IIUM Press

Alexon, A. (1999). Counseling \& development in multicultural society ( ${ }^{\text {rd }}$ edn.). Brooks/Cole Publishing Co.

Amato, P.R. (1986)."Marital conflict, the parent-child relationship and child self-esteem". Journal on Family Relations, 35, 403-410

Amato, P.R. (1996)."Explaining the intergenerational transmission of divorce. Journal of" Marriage and the family, 58, 628-640.

Amato, P.R. (1994). "Life-Span adjustment of children to their parents' divorce." Children of Divorce, Vol. 4 No. 1 Spring 1994

Amato, P.R. (1993)."Children's adjustment to divorce: theories, hypotheses, and empirical support". Journal of Marriage and the Family, 55 , 23-28

Amato, P.R. \& Booth, A. (1997). A generation risk: Growing up in an era of family upheaval. Cambridge, MA: Harvard University Press

Amato, P. R. \& Booth, A. (1991). "Consequences of parental divorce and marital unhappiness for adult well-being". Social Forces 69, 895-914.

Amato, P.R. \& Booth, A. (1996). "A prospective study of divorce and parent-child relationship." Journal of Marriage and Family, 58, 256-365.

Amato, P.R. \& D.D. DeBoer (2001). "The transmission of marital instability across generations: Relationship skills or commitment to marriage." Journal of Marriage and the Family

Amato, P.R., \& Keith, B. (1991a). "Parental divorce and the well-being of children: A metaanalysis." Psychological Bulletin, 110, 26-46.

Amato, P.R. \& Keith, B. (1991b). "Parental divorce and adult well-being: A meta-analysis." Journal of Marriage and the Family, 53, 43-58

Amato, P.R. \& Rogers, S. J. (1999). "Do attitudes toward divorce affect marital quality?" Journal of Family Issues, 20, 69-86.

Andre, S. et.al. (2006). "Childhood predictors of male criminality: A prospective populationbased follow-up study from age 8 to late adolescence." Journal of the American Academy of child \& Adolescent Psychiatry 45: 578-586

Aquilino, W.S. (1997). "From adolescent to young adult: A prospective study of parent-child relations during transition to adulthood". Journal of Marriage and the Family, 50, 670-686

Argyle, M. (1987). Psychology of happiness. London: Methven

Aro, H. M., \& Palosaari, U.K. (1992). "Parental divorce, adolescence, and transition to young adulthood: A follow-up study". American Journal of Orthopsychiatry, 62 (3), 421-429

Aseltine, R. H. Jr. (1996). "Pathways linking parental divorce with adolescent depression". Journal of Health and Social Behavior 37: 133-48 
IIUM Journal of Educational Studies, 1:1 (2013) 55-97

Copyright (C) IIUM Press

Atwater, E. (1994). Psychology for living: adjustment, growth, and behavior today ( $5^{\text {th }}$ edn.). Prentice Hall

Ayoub, M. (2004). Islam: faith and history. Oxford

Baron, R. et al (2006). Social psychology (11 ${ }^{\text {th }}$ edn.). Pearson Rducation Inc. USA

Baruth, L.G. \& Lee, M. (2003). Multicultural counseling and psychotherapy: A lifespan perspective ( $3^{\text {rd }}$ edn.). Merril Prentice Hall, N.J. Ohio

Becker, H.S. (1986). Doing things together. Evanston, IL: Northwestern University Press

Bogdan, R., \& Biklen, S.K. (1992). Qualitative research for education: An introduction to theory and methods ( $2^{\text {nd }}$ edn.). Boston, Ally \& Bacon.

Bogenschneider, K. W.; Rafaelli, M. \& Tsay, J.C. (1998). "Parent influences on adolescent peer orientation and substance use: The interface of parenting practices and values." Journal on Child Development.

Bowlby, J. (1973). Attachment and loss: Vol. II. Separation. London: Hogarth Press.

Bowlby, J. (1988). A secure base: Parent-child attachment and healthy human development. New York: Basic Books.

Buchanan, C.M., Macoby, E.E., \& Dornbusch, S.M. (1991). "Caught between parents: Adolescents' experience in divorced homes." Child Development, 62, 1008-1029

Burke, M.T. et. Al., (1995). Counseling: the spiritual dimension. Alexandria, VA: American Counseling Association

Burns, A., \& Dunlop, R. (1998). "Parental divorce, parent-child relations, and early adulthood relationships: A longitudinal Australian study." Personal Relationships, 5, 393-407.

Cantin, S., \& Boivin, M. (2004). "Change and stability in youngster's social network and selfperceptions during transition from elementary to junior highschool." International Journal of Behavioral Development, 28, 561-570

Cebollero, A.M., Cruise, K., \& Stollack, G. (1986). "The long-term effects of divorce:

Mothers and children concurrent support groups." Journal of Divorce, 10 (1/2), 219-228

Chase-Landsdale, P.L., Cherlin, A.J., \& Kiernan, K. E. (1995). "The long-term effects of parental divorce on the mental health of young adults: A developmental prespective." Child Development, 66, 1614-1634

Cherlin, A.J. (1999). Longitudinal studies of effects of divorce on children in Great Britain and the US. John Hopkins University, Baltimore, MD

Chilton, R., \& Markle, G. (1972). "Family disruption, delinquent conduct, \& the effects of subclassification" American Sociological Review 37: 93-99

Creswell JW. Qualitative inquiry and research design: Choosing among the five traditions. Thousand Oaks, CA: Sage. 
IIUM Journal of Educational Studies, 1:1 (2013) 55-97

Copyright (C) IIUM Press

Cooney,T.M. (1998). "Young adults and parental divorce: Exploring important issues." Human Relations, 4, 805-822

Cooney, T.M. (1994). "Young adults' relations with parents: The influence of recentparental divorce." Journal of Marriage and the Family, 56, 45-56

Cooney, T.M. \& Kurz, J. (1996). "Mental health outcomes following recent parental divorce." Journal of Family Issues, 17, 495-513

Cutrona, C.E. (1989). "Ratings of social support by adolescent and adult informants: Degree of correspondence and prediction of depressive symptoms." Journal of Personality and Social Psychology, 57, 723-730

Denzin, N.K. \& Lincoln, Y.S. (2008). The landscape of qualitative research: NY Sage Publication

Derlega, V.J. \& Janda, L.H. (1986). Personal adjustment: the psychology of everyday life (3 ${ }^{\text {rd }}$ edn.). Scott, Foresman \& Co. USA

Doucet, J. \& Aseltine, R. H. Jr. (2003). "Childhood family adversity and the quality of marital relationships in young adulthood." Journal of Social and Personal Relationships, 20 (6): 818-842

Duffy, K.G. \& Atwater, E. (2002). Psychology for living: Adjustment, growth \& behavior today $\left(7^{\text {th }}\right.$ edn.). Prentice Hall

Erikson, E.H. (1959). Identity and the life cycle. New York: International Universities Press.

Furstenberg, F.F. Jr. (1990). "Divorce and the American family." Annual Review of Sociology, $16379-403$

Furstenberg, F.F., Peterson, J.L., Nord, C. W. \& Zill, N. (1983). "The life course of children of divorce: Marital disruption and parental contact." American Sociological Review, 48, 656-668.

Furstenberg, F.F. Jr., \& Cherlin, A.J. (1991). Divided families: what happens to children when parents part. Cambridge, MA: Harvard University Press

Furstenberg, F.F., Jr., \& Teitler, J.D. (1984). "Reconsidering the effects of marital disruption: What happens to children of divorce in early adulthood?" Journal of Family Issues, 15, 173-190.

Gabardi, L., \& Rosen, L. A. (1991). "Differences between college students from divorced and intact families." Journal of Divorce and Remarriage, 15, 175-191

Gabardi, L., \& Rosen, L. A. (1992). "Intimate relationships: College students from divorced and intact families." Journal of Divorce and Remarriage, 15, 25-26

Gaskel, G. (2000). Individual and group interviewing. Sage Publications

Glesne, C. \& Peshkin, A. (1992). Becoming qualitative researchers. White Plains, NY: Longman 
IIUM Journal of Educational Studies, 1:1 (2013) 55-97

Copyright (C) IIUM Press

Gweck, S. \& Gweck, E. (1980). Unraveling juvenile delinquency. Cambridge, MA: Harvard University Press

Healy, J.M., \& Stewart, A. J. (1991). "On the compatibility of quantitative and qualitative methods for studying individuals lives." Perspective in Personality, (3), 35-37, Jessical Kingsley Publishers Ltd.

Hetherington, E.M. (1989). "Coping with family transitions: Winners, losers, and survivors." Child Development, 60, 1-14.

Hetherington, E.M., Cox, M., \& Cox, R. (1978). "The aftermath of divorce." In J.H. Steven, Jr., \& M. Matthews (Eds.), Mother-child, father-child relations. Mahwah, NJ: Lawrence Erlbaum.

Kalter, N. (1987). "Long- term effects of divorce on children: A developmental vulnerability model." Americal Journal of Orthopsychiatry, 57 (4), 587-600.

Kalmijn, M. (1994) "Mother's Occupational Status and Children's Schooling'" American Sociological Review 59: 257-75

Kurtz, L., \& Derevensky, J.L. (1993). "The effects of divorce on perceived self-efficacy and behavioral control in elementary school children." Journal of Divorce \& Marriage, (20) (3/4), 75-94.

Thomas Holmes and Richard Rahe. "Homes-Rahe social readjustment rating scale." Journal of Psychosomatic Research, Vol II, 1967.

Johnson, S.G., \& Thomas, A.M. (1996). "Divorce versus intact parental marriage and perceived risk and dyadic trust in present heterosexual relationships." Psychological Report, 78, 387-390.

Kapala, M. \& Suzuki, L.A. (1999). Using qualitative methods in psychology. Sage Publications

Krein, S.F. \& A.H. Beller (1998). "Educational attainment of children from single-parent families: Differences by exposure, gender, and Race." Demography 25221-34

Lincoln, Y.S. \& Guba, E.G. (1985). Naturalistic inquiry. Beverly Hills , CA: Sage Publications

Loewenstein, G., Weber, E., Hsee, C. and Welch, N. (2001). "Risk as Feelings." Psychological Bulletin, 127, 267286.

Long, N., \& Forehand, R. (1987). "The effects of parental divorce and parental conflict on children: An overview." Developmental and Behavioral Pediatrics, 8 (5), 292-296.

Merriam, S.B. (2001). Qualitative research and case study applications in education ( $^{\text {nd }}$ edn.). San Francisco: Jossy-Bass

McCormick, C.B., \& Kennedy, J.H. (1994). "Parent-child attachment working models \& selfesteem in adolescence." Journal of Youth \& Adolescence, 23 1-18 
IIUM Journal of Educational Studies, 1:1 (2013) 55-97

Copyright (C) IIUM Press

Miles, M.B., \& Huberman, A.M. (1994). Qualitative data and analysis (2 ${ }^{\text {nd }}$ edn.). London: Sage Ltd.

Miller, D.C. (1991). Handbook of research design and social measurement ( $5^{\text {th }}$ edn.). Sage Publication

Morrison, D. R. \& A.J. Cherlin (1995) "The divorce process and young children's well-being: A prospective Analyis." Journal of Marriage and the family, 57: 800-12

Nair, H., \& Murray, A.D. (2005). "Predictors of attachment security in preschool children from intact and divorced familes." Journal of Genetic Psychology, 166, 245-263

O’Brien, M., et al. (1997). "Child exposure to marital conflict and child doping responses as predictors of child adjustment." Cognitive Therapy and Research, 21 (1), 39-59

Oderberg, N. (1986). "College students from divorced families: The impact of post-divorce life on long-term psychological adjustment." Conciliation Courts Review, 24(1), 103-110.

Oppawsky, J. (1991)."The effects of parental divorce on children in West Germany: Emphasis: From the view of the children." Journal of Divorce and Remarriage, 16(3/4), 291-304

Patton, M. Q. (2002). Qualitative evaluation and research methods ( $3^{\text {rd }}$ edn.). Thousand Oaks, CA: Sage.

Patton, M. (1990). Qualitative evaluation and research methods ( $2^{\text {nd }}$ edn.). Newbury Park, CA: Sage Publication

Palmer, S. (2002). Multicultural counseling-A reader. Sage Publication

Polkinghorne D. (1989). Phenomenological research methods. In: Valle SR, Halling S, eds. Existential-phenomenological perspective in psychology. New York: Plenum Press.

Rosen, R. (1977). "Children of divorce: What they feel about access and other aspects of the divorce experience." Journal of Clinical Psychology, 6, 24-27.

Rogers \& Rogers, (2002). "Adult Children of Divorced Parents: Making Your Marriage Work." Resource Publications

Runyon, N., \& Jackson, P.L. (1988). "Divorce: Its impact on children." Perspectives in psychiatric care, 24 (3/4), 101-105.

Santrock, J.W. (2006). Human adjustment. McGraw Hill.

Santrock, J.W., \& Warshak, R.A. (1979). "Father custody and social development in boys and girls." Journal of Social Issues, 35, 112-125.

Sedlacek, W.E. (1987). "Black students on White campuses: 20 years of research." Journal of College Student personnel, 28 (6) , 484-495.

Segrin C., et al. (2005). "Social cognitive mediators and relational outcomes associated with parental divorce." Journal of Social and Personal Relationships. 22 (3): 361-377 
IIUM Journal of Educational Studies, 1:1 (2013) 55-97

Copyright (C) IIUM Press

Shaw, D. S., (1991). The effects of divorce on children's adjustment: Review and implications. Behavior modification, 15 (4), 456-485.

Shukri, A. (1996). Muhammedan law of marriage and divorce. New York: AMS

Silverman, D. (2000). Doing qualitative research: A practical handbook. London: Sage Ltd.

Somekh, B. \& Lewin, C. (2005). Research Methods in the social sciences. Sage Publication

Spigelman, A., \& Spigelman, G. (1991). "The relationship between parental divorce and the child's body boundary definiteness." Journal of Personality Assessment, 56 , 96-105

Spigelman, A., Spigelman, G., \& Englesson, I.L. (1994). "The effects of divorce on children: Post-divorce adaptation of Swedish children to the family breakup: Assessed by interview data and Rorschach responses. Journal of Divorce and Remarriage, 21 (3/4), 171-190.

Stabb, S. D. (1999). Teaching qualitative research in psychology. Sage Publications

Strauss, A. \& Corbin, J. (1998). Basics of qualitative research $\left(2^{\text {nd }}\right.$ edn.). Newbury Park, CA: Sage.

Tanji, J.M. (1999). "Capturing the process of family therapy as social merging construction." p. 163

Tasker, F.L. (1992). "Anti-marriage attitudes and motivations to marry amongst adolescents with divorced parents." Journal of Divorce and Remarriage, 18, 105-119.

Toby, J. (1987). "The differential impact of family disorganization." American Sociological Review 22: 505-512

Travers, M. (2002). Qualitative research through case studies. NY Sage Publication

U.S. Census Bureau. (2002). America's families and living arrangements: Current Population Reports

Wadsworth, M., McLean, M., Kuh, D., \& Rodgers, B. (1990). "Children of divorced and separated parents: Summary and review of findings from a long-term follow-up study in the UK." Family Practice, 7, 104-109.

Wallerstein, J. (1991). "The long-term effects of divorce on children. A review." Journal of the American Academy of Child Adolescent Psychiatry, 30, 349-360.

Wallerstein, J.S. (1985). "The overburdened child: some long-term consequences of divorce." Social Work, 30 (2), 116-123.

Wallerstein, J.S., \& Kelly, J.B. (1980). Surviving the breakup: How children and parents cope with divorce. New York: Basic Books

Wallerstein, J.S. et.al., (1983). "The Unexpected Legacy of Divorce: The 25 Year Landmark Study."American Journal of Orthopsychiatry. 
IIUM Journal of Educational Studies, 1:1 (2013) 55-97

Copyright (C) IIUM Press

Warga, R. Personal Awareness: A psychology of adjustment $3^{\text {rd }}$ edn.. Houghton Mifflin Co., Boston

Wauck, J. (1989). "Putting Asunder: A History of Divorce in Western Society "Book Reviews (National $\quad$ Review) FindArticles.com. 202008. http://findarticles.com/p/articles/mi_m1282/is_n9_v41/ai_7600933

Weiten, W. \& Lloyd M.A. (2000). Psychology applied to modern life. Waddsworth

Weiten, W. \& Lloyd, M.A. (1991). Psychology applied to modern life adjustment in the 90s. Brooks/Cole Publishing Co.

Weingarten, H.R. (1985). "Marital Status and Well-Being: A National Study Comparing FirstMarried, Currently Divorced, and Remarried Adults." Journal of Marriage and the Family, Vol. 47, No. 3 (Aug., 1985), pp. 653-662

Westervelt, K., \& Vandenberg, B. (1997). "Parental divorce and intimate relationships of young adults." Psychological Reports, 80, 923-926.

Williams, B. K. (2006). Marriages, families, and intimate relationships: A practical introduction. Pearson Education Inc. USA 